Greenland, were joined in 1992 by activities in northern Greenland as far north as $83^{\circ} \mathrm{N}$ (Platinova $\mathrm{A} / \mathrm{S}$ and Nanisivik Mines Ltd), marking a resoluteness to extend the search for economic minerals to the world's northernmost territories.

\section{Regulatory and licensing information}

New licences. Twenty new exploration licences regarding minerals have been granted for the 5-year period 1992-96.

Favourable taxation rules. In spring 1992 several particularly favourable rules concerning mineral resources activities were adopted.

\section{References}

Larsen, L. M. 1991: Occurrences of kimberlite, lamproite and ultramafic lamprophyre in Greenland. Open File Ser. Grønlands geol. Unders. 91/2, $36 \mathrm{pp}$.

MRA, 1990: Report from The Strategy Group for Mineral Resources in Greenland, 76 pp. Copenhagen: Mineral Resources Administration for Greenland.

Pulvertaft, T. C. R. 1991: 1990 - a year of change in hydrocarbon-geological activities at the Geological Survey of Greenland. Rapp. Gronlands geol. Unders. 152, 11-13.

Thomassen, B. \& Tukiainen, T. 1992: Gold mineralisation in Precambrian supracrustal rocks on southern Nuussuaq, central West Greenland: 1991 results. Open File Ser. Grønlands geol. Unders. 92/3, 31 pp.

P. R. D. \& H. H. T., Geological Survey of Greenland, Copenhagen.

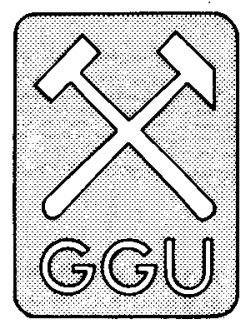

\title{
Greenland mineral resource information to industry: increased scope in 1992
}

\author{
Peter R. Dawes, Hans K. Schønwandt \\ and Bjørn Thomassen
}

The year 1992 has seen an expansion in the scope of the Geological Survey of Greenland's (GGU) information service to the mining industry. In the preceding few years this part of GGU's work has been improved by a number of facilities, ranging from the establishment in Copenhagen of a Mineralisation Data Bank and Core Library to a new publication policy aimed at streamlining the processing time and availability of in-house geological data, as well as ensuring improved public access to released company data stemming from concessionary exploration work in Greenland (see Ghisler 1990, 1992; Schønwandt, 1991). A more recent venture has been the introduction of a newsletter - reported on elsewhere in this report (Dawes \& Thomsen).
The widening in scope of GGU's information service is led by two broad initiatives launched in collaboration with the Mineral Resources Administration for Greenland (MRA); both are designed to promote international interest in the mineral potential of Greenland and both involve presentation of geological data at venues away from headquarters in Copenhagen. The first, a promotion campaign in North America and Europe, provides an on-the-spot service to international exploration and mining audiences; the second took the form in 1992 of an open excursion to mineralisation showings in part of East Greenland, arranged to give potential investors first-hand knowledge of the island's economic geology, logistics and field conditions. 
This note briefly describes the 1992 activities under the new initiatives. Both initiatives are planned to continue in future years.

\section{International promotion campaign}

In 1992 this campaign consisted of a lecture-posterbooth programme on the general theme: 'Greenland's exploration and mineral potential'. The travelling demonstration, manned by both GGU and MRA personnel, covered both geoscientific and exploratory data, as well as legislatory and licensing aspects. The programme started in Canada in January with meetings in four major cities and was followed up by a return to Toronto in March; visits were also made to Britain, Northern Ireland and Spain, and the year was concluded in December with a tour in western U.S.A.

Venues ranged from the traditional meeting places of commercial geologists, mining companies and investors, such as annual conventions and trade shows arranged by geological organisations or mining associations, to independent meetings and receptions, advertised internationally and supplemented by direct invitation. The list below contains the main 1992 venues.

- Open session and reception, Toronto, Canada

- Polar Tech '92, Annual Conference, Polar Technology: A global challenge, Montreal, Canada

- Geological Forum and Mineral Colloquium, Geological Survey of Canada, Ottawa, Canada

- 9th Annual Cordilleran Geology and Exploration Roundup, British Columbia \& Yukon Chamber of Mines, Vancouver, Canada

- Open session and reception, London, England

,- Annual Convention \& Exhibition, Prospectors and Developers Association of Canada, Toronto, Canada

- Euro-Exploration meeting, Irish Association for Economic Geology, Newcastle, Northern Ireland

- 15th World Mining Congress \& Exhibition, Madrid, Spain

- 98th Annual Convention \& Trade Show, Northwest Mining Association, Spokane, U.S.A.

Apart from the presentation of specific exploratory targets and a description of the geological setting of Greenland's main metallogenic provinces, the overriding message at these gatherings has been that "Greenland is now ready, willing and open for business". Promising mineral potential, coupled with the new mining legislation introduced in 1991, has created a hope that Greenland will prove to be attractive and competitive to foreign investment. This message has

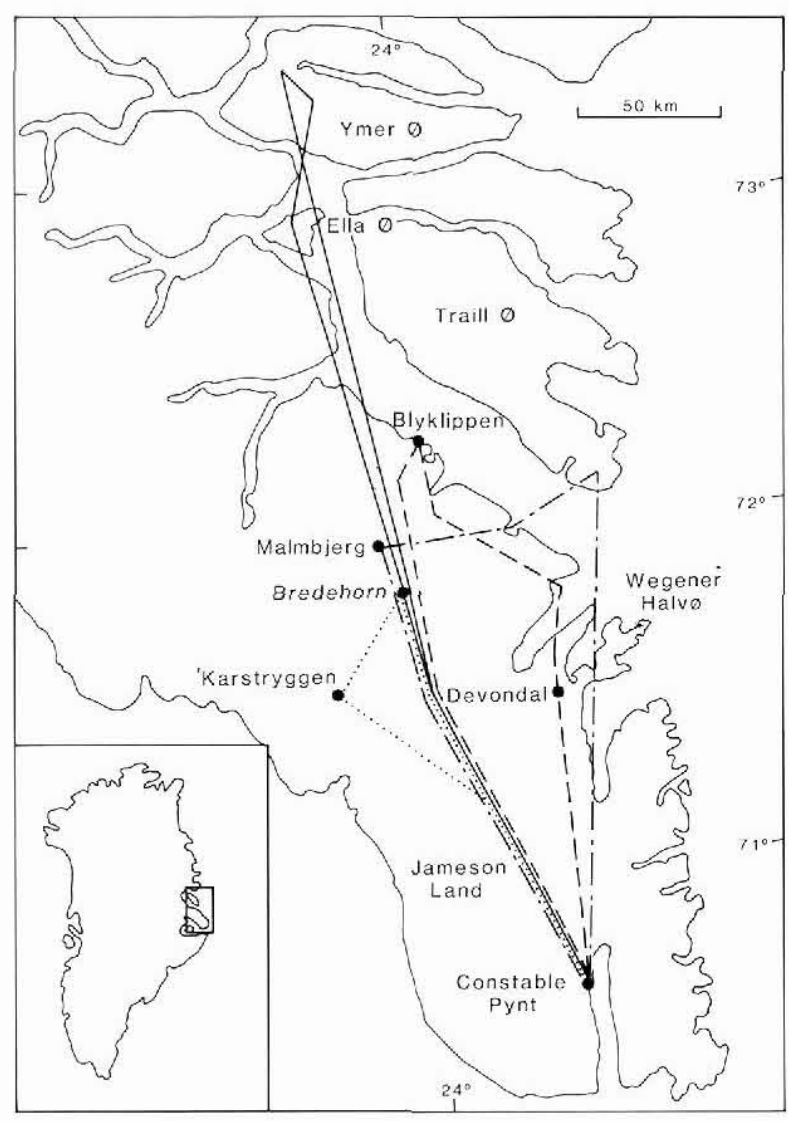

Fig. 1. Sketch map of central East Greenland showing the main localities visited by the mineral exploration excursion.

been reiterated in the international mining and arctic literature (see e.g. Mining Journal, 1991, 1992; Circumpolar notes 1992; Svela, 1992, 1993; Yohannes \& Prast, 1993).

While on tour, meetings were held with representatives of a number of mining companies and, in Canada, with provincial and federal organisations concerned with exploration and mining, including in Ottawa and Calgary personnel of the Geological Survey of Canada (GSC). GSC, as GGU's parallel state organisation, representing Greenland's nearest neighbour, celebrated in 1992 " 150 years of service to the nation" that includes strong links to industry. A recent announcement by GSC is of a massive geological exploration programme financed jointly with industry, an approach of some relevance in the present campaign to realize Greenland's mineral potential. 


\section{Greenland mineral excursion}

To help in the evaluation of the mineral exploration possibilities and to give potential investors a chance to experience at first hand something of Greenland, its geology and mineralisation, an excursion to central East Greenland was arranged in the period 15 th to 20 th July (Figs $1 \& 2$ ). The excursion was advertised internationally during the promotion campaign described above. Logistics, based on helicopter and small fixed-wing aircraft, determined that participation was limited and the excursion finally was carried out with six exploration geologists, guided by a GGU geologist. Applications were accepted on a first come, first served basis, and as it turned out, the six participants represented but two companies, the Australian-American BHP Minerals and Canadian LAC Minerals.

The excursion was mobilised through Iceland where prior to departure to Greenland a representative of the MRA reported on mining legislation. In Greenland the party met local politicians, senior mineral officials and journalists. The field work was blessed by excellent weather; four days of unbroken sunshine. Base for the operation was Constable Pynt, Jameson Land, an airport facility built during the commercial hydrocarbon exploration programme led by ARCO in the 1980 s (Fig. 1).

The localities visited between latitudes $71^{\circ}$ and $73^{\circ} \mathrm{N}$ in central East Greenland represent deposits that have seen commercial exploitation as well as current targets in the early exploration stage. The first day concentrated on the Tertiary intrusions with the main highlight being the 150 million tons $0.23 \% \mathrm{MoS}_{2}$ porphyry deposit Malmbjerg (Fig. 2), and examination of extensive rust zones on Traill $\emptyset$ that have a potential for gold. The following two days concerned Permo-Triassic base metal and baryte mineralisation in carbonate sediments and quartz veins. These included the Permian 0.5 million tons $9 \%$ lead, $10 \%$ zinc Blyklippen deposit now worked out, an Upper Permian 'zebra-baryte' locality at Bredehorn, the Triassic copper-silver mineralisation at Devondal and various localities on Wegener Halvø with syngenetic and epigenetic mineralisation. The final field day was devoted to gold, antimony and tungsten occurrences in Caledonian sediments, and during this the excursion was joined by John Pedersen, chief geologist of Nunaoil A/S, who showed the group the ongoing exploration work for gold on Ymer $\emptyset$ as well as nearby base metal and antimony-tungsten showings.

The excursion that covered over $1800 \mathrm{~km}$ by helicopter also found time to call in on other, less mineral oriented activities, such as the international group on the trail of dinosaurs in northern Jameson Land and a visit to Ella $\varnothing$, historically famous as the headquarters of Lauge Koch who instigated the mapping of East Greenland in 1926 and led a continuous series of expeditions to the region up to 1958 .

\section{References}

Circumpolar notes 1992: The Geological Survey of Greenland looks to Canada for investment and expertise. Circumpolar notes 1(5), 5 only. Ottawa: Circumpolar and Scientific Affairs Directorate.

Ghisler, M. 1990: Towards a new decade in Greenland geology. Rapp. Grønlands geol. Unders. 148, 7 only.

Ghisler, M. 1992: Review of the Survey's activities in 1991. Rapp. Grønlands geol. Unders. 155, 7-8.

Mining Journal 1991: Greenland: new legislation to attract investors. Mining J. 317(8137), 157-159.

Mining Journal 1992: Greenland - Breaking the ice. Mining J. 319, 77-79.

Schønwandt, H. K. 1991: Economic mineral resources: activities in 1990. Rapp. Grønlands geol. Unders. 152, 41-46.

Svela, O. 1992: Greenland rewrites regulations governing mining development. The Northern Miner 78(22), 1-2. Ontario, Canada.

Svela, O. 1993: Greenland flashes the green light. The Northern Miner Magazine 8(1), S17-S28. Ontario, Canada.

Yohannes, W. W. \& Prast, W. G. 1993: Attracting investors: what is to be done? Mining Mag. 1993 (Jan.), 12-16.

P. R. D., H. K. S. \& B. T., Geological Survey of Greenland, Copenhagen.

Fig. 2. Above: lunch break during the mineral exploration excursion to central East Greenland. View is across the fault-controlled valley that separates the late Palaeozoic-Mesozoic Jameson Land Basin from the Caledonian crystalline rocks to the left. Height of section about $2 \mathrm{~km}$. Arrow marks location of view below. Below: the porphyry molybdenum deposit, Malmbjerg. A Tertiary alkaline granite intruded into Permo-Carboniferous sediments. Photos: Bjørn Thomassen. 

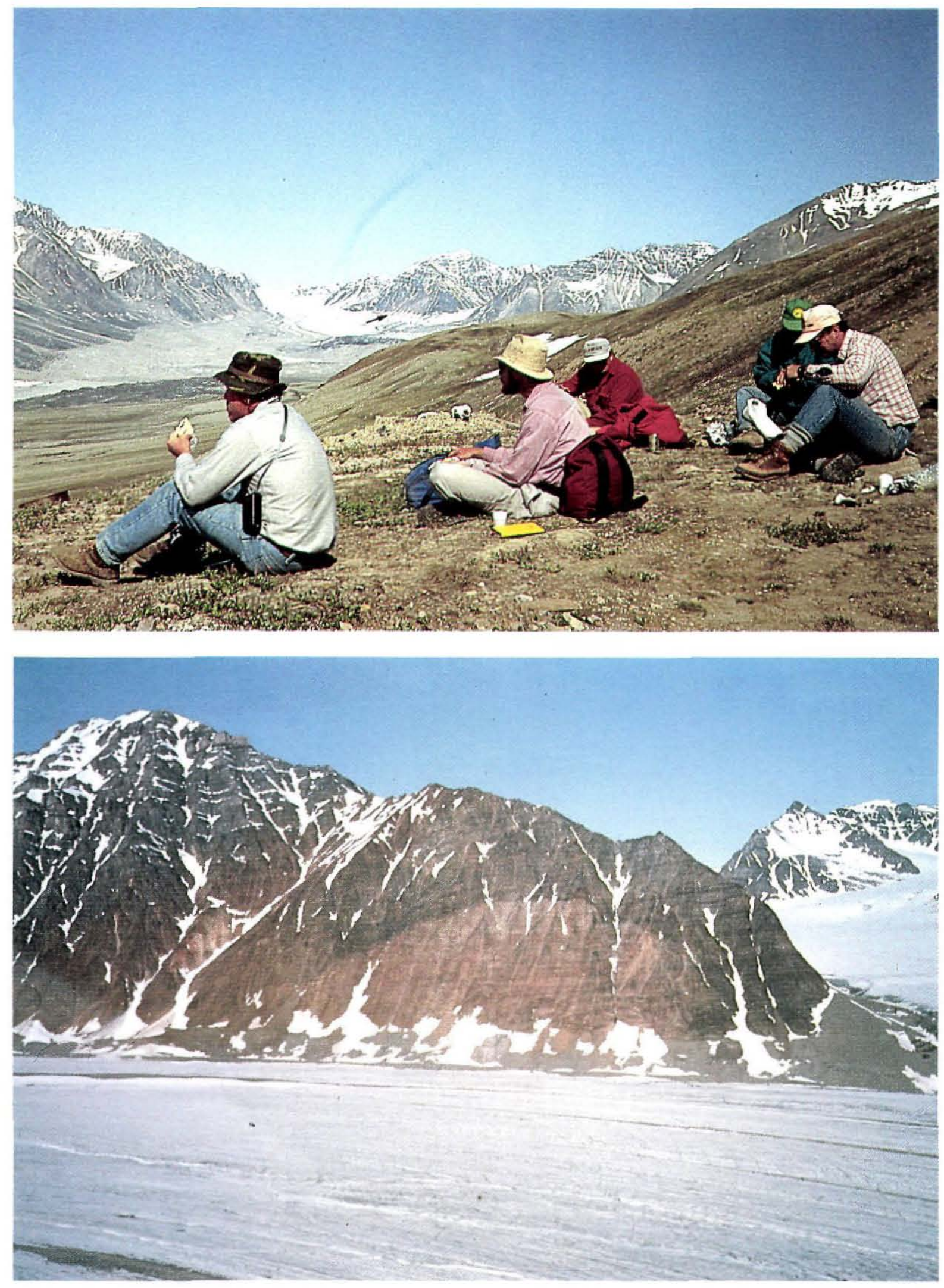